\title{
PENGARUH MODEL PEMBELAJARAN BERBASIS MASALAH TERHADAP AKTIVITAS BELAJAR SISWA KELAS VII PADA MATERI SALING KETERGANTUNGAN DALAM EKOSISTEM
}

\author{
Pratiwi $^{1) a)}$, Erie Agusta ${ }^{2)}$ \\ ${ }^{1)}$ Prodi Pendidikan Biologi, Fak. Ilmu Tarbiyah dan Keguruan, UIN Raden Fatah Palembang \\ Jl. Prof. K. H. Zainal Abidin Fikri No. 1 A KM 3.5, Palembang 30126, Indonesia. \\ ${ }^{2)}$ Fakultas Keguruan dan Ilmu Pendidikan, Universitas Muhammadiyah Palembang \\ Jl. Ahmad Yani Plaju, Palembang 30126, Indonesia.
}

a)Pratiwijaya93@gmail.com

\begin{abstract}
Problem-based learning model is a learning activity that requires physical and mental activity of students to understand a learning material through situations and problems presented at the beginning of learning with the aim to train students solve the problems by using problem-solving approach. This study aims to see the effect of problem-based learning model on student learning activities on the material interdependence in the ecosystem VII class. Variables in this research are problem-based learning model as independent variable and learning activity as dependent variable. The sample of this research is VII.C class as experiment class and VII.D class as control class. The method used in this research is all experimental method. Data collection techniques used were questionnaires and observation sheets to determine the level of student learning activity after applied problem-based learning model. $\mathrm{H}_{0}$ rejected and $\mathrm{Ha}$ accepted which means there is influence of problem-based learning model to student learning activities on the ecosystem materials.
\end{abstract}

Keywords: learning activity, learning based on problem, ecosystem

\section{PENDAHULUAN}

Saat ini banyak ditemukan masalah-masalah dalam dunia pendidikan terutama di bidang pendidikan IPA. Hal ini sejalan dengan pendapat Djumadi (2010) yang menyatakan bahwa, pada kenyataannya banyak siswa yang tidak menyukai mata pelajaran IPA. IPA merupakan mata pelajaran yang sukar dan sulit untuk diingat. Hal itu merugikan karena akan berdampak pada rendahnya penguasaan materi pelajaran. Siswa tidak dapat mengikuti pelajaran dengan lancar, prestasi belajar yang rendah meskipun telah diusahakan untuk belajar dengan sebaik-baiknya. Permasalahan tersebut dapat muncul akibat dari tidak aktif nya siswa dalam kegiatan belajar mengajar di kelas dengan peran siswa menjadi sangat pasif ketika guru cenderung lebih aktif mentransfer ilmu tanpa melibatkan sisi psikomotorik anak.

Permasalahan yang terjadi adalah siswa cenderung pasif dalam mengikuti proses pembelajaran. Selain itu, tidak antusiasnya siswa dalam membaca dan mempelajari bahan ajar yang disediakan, malu bertanya tentang materi yang tidak mereka pahami serta tidak berani mengemukakan pendapat. Selain itu rasa tanggung jawab, toleransi, dan kerjasama dalam diri siswa juga masih rendah.
Hal ini terlihat ketika siswa diminta mengerjakan tugas dengan cara berdiskusi hanya beberapa orang saja yang terlibat dalam diskusi sementara siswa yang lain bercerita dengan temannya. Selain itu siswa masih kurang teliti dan ceroboh dalam mengerjakan tugas dan sering mengumpulkan tugas tidak tepat waktu.Ini menunjukkan bahwa kurang aktifnya siswa dalam kegiatan pembelajaran. Selanjutnya sewaktu guru memberikan evaluasi, masih banyak siswa yang mencontek jawaban temannya. Hal ini menunjukkan bahwa sikap percaya diri siswa masih kurang yang diakibatkan dari rendahnya aktivitas psikomotor siswa selama kegiatan pembelajaran.

Berdasarkan investigasi terhadap siswa, masyarakat sekitar sekolah dan juga guru, didapati latar belakang siswa yang sekolah di salah satu MTs di Palembang sebanyak $65 \%$ berasal dari panti asuhan. Siswa yang berasal dari panti asuhan pola asuhnya tentu akan berbeda dengan siswa yang langsung dibimbing oleh orang tua, dan siswa yang berada di panti asuhan biasanya akan sulit dalam membuka diri terhadap hal-hal baru. Selain itu, siswa yang berada di panti asuhan tidak akan mendapat bimbingan belajar seperti yang didapatkan anak dari orang tua sedangkan untuk 
fasilitas yang didapat anak dari panti asuhan tentunya tidak akan sama dengan fasilitas yang diberikan oleh orang tua. Hal tersebut tentu akan mempengaruhi kondisi psikologis dan psikomotorik siswa ketika mengikuti kegiatan belajar mengajar di kelas. Aktivitas belajar siswa juga dipengaruhi oleh kemampuan seorang guru dalam menerapkan suatu model pembelajaran di kelas. Rusman (2014) menyatakan bahwa aktivitas belajar siswa harus selalu diciptakan dan berjalan terus dengan menggunakan model pembelajaran yang tepat.

Model pembelajaran berbasis masalah adalah suatu model pembelajaran yang sesuai untuk menjawab permasalahan tersebut karena model pembelajaran berbasis masalah adalah suatu model yang menitik beratkan permasalahan pada aktivitas psikomotorik siswa. Hal ini sejalan dengan pendapat Rusman (2014) yang menyatakan bahwa model pembelajaran berbasis masalah berorientasi pada pandangan konstruktivistik. Pandangan konstruktivistik memuat karakteristik kontekstual, kolaboratif, berpikir metakognisi, dan memfasilitasi pemecahan masalah. Siswa dimungkinkan belajar secara bermakna yang dapat mengembangkan kemampuan berpikir tingkat tinggi melalui pemecahan masalah. Pembelajaran ini diharapkan mampu meningkatkan pemahaman akan makna, meningkatkan kemandirian, meningkatkan pengembangan skill berpikir tingkat tinggi, meningkatkan motivasi dan aktivitas belajar, memfasilitasi relasi antar siswa dan meningkatkan skill dalam membangun pengetahuan akan pemecahan masalah.

Model pembelajaran berbasis masalah merupakan sebuah model pembelajaran yang berdasarkan permasalahan dan didominasi oleh siswa (student center) dan dicirikan oleh adanya keterbukaan, proses demokrasi, dan peran aktif siswa. Keseluruhan proses yang terjadi dalam pelaksanaan berdasarkan masalah diharapkan dapat membantu siswa untuk memilki kemandirian, percaya pada keterampilan intelektual yang dimiliki siswa, dan keterlibatan aktif dalam proses inkuiri (Cahyo, 2013). Model pembelajaran berbasis masalah mengacu pada suatu teori pembelajaran belajar Jerome S. Bruner yang menyatakan bahwa metode siswa menemukan kembali namun bukan menemukan yang sama sekali benar-benar baru. Belajar penemuan sesuai dengan pencarian pengetahuan secara aktif oleh manusia dengan sendirinya memberikan hasil yang lebih baik, berusaha sendiri mencari pemecahan masalah didukung oleh pengetahuan yang menyertainya, dan menghasilkan pengetahuan yang benar-benar bermakna (Fadly, 2012).

Berdasarkan uraian tersebut maka perlu dilakukan sebuah penelitian yang berjudul pengaruh model pembelajaran berbasis masalah terhadap aktivitas belajar siswa pada materi saling ketergantungan dalam ekosistem di kelas VII MTs. Penelitian ini diharapkan mampu membantu pendidik untuk lebih meningkatkan aktivitas belajar siswa di kelas (Dahar, 1996).

\section{METODOLOGI PENELITIAN}

Jenis penelitian ini adalah metode eksperimen semu (quasi experiment) dengan menggunakan pendekatan kuantitatif. Populasi dan sampel pada penelitian ini adalah 80 orang siswa. Teknik pengambilan data melalui angket dan lembar observasi. Kemudian data dianalisis normalitas dan homogenitas yang merupakan prasyarat untuk melakukan uji hipotesis (uji-t) (Simanjuntak, 2014).

\section{HASIL DAN PEMBAHASAN}

Berdasarkan hasil perhitungan angket dan lembar observasi mengenai aktivitas belajar siswa pada kelas eksperimen dan kelas kontrol diperoleh data yang disajikan pada Tabel 1 .

\section{Tabel 1. Data Statistik Aktivitas belajar siswa}

\begin{tabular}{|c|c|c|c|c|}
\hline \multirow[b]{2}{*}{ Data Statistik } & \multicolumn{2}{|c|}{ Angket } & \multicolumn{2}{|c|}{ Lembar Observasi } \\
\hline & $\begin{array}{c}\text { Kelas } \\
\text { Eksperimen }\end{array}$ & Kelas Kontrol & $\begin{array}{c}\text { Kelas } \\
\text { Eksperimen }\end{array}$ & $\begin{array}{c}\text { Kelas } \\
\text { Kontrol }\end{array}$ \\
\hline Jumlah Siswa & 20 & 21 & 20 & 21 \\
\hline Mean & 82,70 & 70,48 & 64,90 & 59,00 \\
\hline Standar Deviasi & 9,217 & 8,953 & 9,431 & 4,658 \\
\hline Nilai Tertinggi & 93 & 84 & 74 & 67 \\
\hline Nilai Terendah & 57 & 53 & 50 & 67 \\
\hline
\end{tabular}

Berdasarkan Tabel 1, rata-rata kedua instrumen pengumpulan data yaitu angket dan lembar observasi. Pada kelas eksperimen dengan menggunakan model pembelajaran berbasis masalah mendapatkan tingkat aktivitas belajar siswa lebih baik jika dibandingkan dengan kelas kontrol yang hanya menggunakan metode diskusi informasi. Berdasarkan hasil perhitungan angket dan lembar observasi mengenai aktivitas belajar 
siswa pada kelas eksperimen dan kelas kontrol

diperoleh data yang disajikan pada Tabel 2.

Tabel 2. Perhitungan Angket Dan Lembar Observasiaktivitas Belajar Siswa

\begin{tabular}{|c|c|c|c|c|}
\hline \multirow{2}{*}{ Data Statistik } & \multicolumn{2}{|c|}{ Angket } & \multicolumn{2}{c|}{ Lembar Observasi } \\
\cline { 2 - 5 } & $\begin{array}{c}\text { Kelas } \\
\text { Eksperimen }\end{array}$ & Kelas Kontrol & $\begin{array}{c}\text { Kelas } \\
\text { Eksperimen }\end{array}$ & Kelas Kontrol \\
\hline Jumlah Siswa & 20 & 21 & 20 & 21 \\
\hline Mean & 82,70 & 70,48 & 64,90 & 59,00 \\
\hline Standar Deviasi & 9,217 & 8,953 & 9,431 & 4,658 \\
\hline Nilai Tertinggi & 93 & 84 & 74 & 67 \\
\hline Nilai Terendah & 57 & 53 & 50 & 67 \\
\hline
\end{tabular}

Berdasarkan Tabel 2, rata-rata kedua instrumen pengumpulan data yaitu angket dan lembar observasi. Pada kelas eksperimen dengan menggunakan model pembelajaran berbasis masalah mendapatkan tingkat aktivitas belajar siswa lebih baik jika dibandingkan dengan kelas kontrol yang hanya menggunakan metode diskusi informasi. Hasil dari persentase kategori aktivitas belajar pada masing-masing siswa baik pada kelas eksperimen maupun pada kelas kontrol disajikan pada Tabel 3.

Tabel 3. Perhitungan Angket Aktivitas Belajar Siswa

\begin{tabular}{|c|c|c|}
\hline Kategori Aktivitas Belajar Siswa & Kelas Eksperimen & Kelas Kontrol \\
\hline Sangat Aktif & $45 \%$ & $0 \%$ \\
\hline Aktif & $45 \%$ & $47,61 \%$ \\
\hline Cukup Aktif & $10 \%$ & $42,85 \%$ \\
\hline Kurang Aktif & $0 \%$ & $10 \%$ \\
\hline Tidak Aktif & $0 \%$ & $0 \%$ \\
\hline
\end{tabular}

Aktivitas belajar siswa pada kelas eksperimen yang termasuk dalam kategori sangat aktif persentasenya sebesar $45 \%$, kategori aktif $45 \%$, dan sisanya yaitu sebesar $10 \%$ termasuk ke dalam kategori cukup aktif. Sedangkan pada kelas kontrol, tidak terdapat siswa yang memiliki kategori aktivitas belajar sangat aktif, tetapi hanya berkisar pada kategori aktif yaitu dengan persentase sebesar $47,61 \%$, kategori cukup aktif yaitu $42,85 \%$ dan sisanya termasuk ke dalam kategori kurang aktif yaitu dengan persentase sebesar 10\%. Setelah melakukan uji prasyarat analisis (uji normalitas dan uji homogenitas) diketahui kedua kelompok kelas berdistribusi normal dan homogen. Kemudian dilakukan uji hipotesis penelitiaan menggunakan SPSS versi 16 dengan analisis parametrik atau dalam hal ini uji hipotesis (uji-t).

Tabel 4. Uji Hipotesis Angket Aktivitas Belajar Siswa

\begin{tabular}{|c|c|c|c|c|c|}
\hline Data & Kelompok & T & Signifikan $(p)$ & $\alpha$ & Keterangan \\
\hline $\begin{array}{c}\text { Aktivitas } \\
\text { belajar siswa }\end{array}$ & Eksperimen & \multirow{2}{*}{3,394} & 0,000 & 0,05 & $\mathrm{H}_{0}$ ditolak \\
\cline { 2 - 6 } & Kontrol & & & \\
\hline
\end{tabular}

Berdasarkan hasil pengujian yang tertera pada output SPSS versi 16 pada tabel independent samples diketahui nilai t sebesar 3,394 dengan nilai signifikan 0,000 (yang artinya nilai signifikan tersebut $<0,05$ ), maka dapat disimpulkan $\mathrm{H}_{0}$ ditolak dan $\mathrm{H}_{\mathrm{a}}$ diterima, artinya terdapat pengaruh yang signifikan dari penerapan model pembelajaran berbasis masalah terhadap aktivitas belajar siswa. Menurut Asiatun (2013), jika nilai t yang dihitung sama dengan atau lebih besar dibandingkan dengan nilai dalam tabel maka hipotesis nol $\left(\mathrm{H}_{0}\right)$ ditolak dan hipotesis alternatif $\left(\mathrm{H}_{\mathrm{a}}\right)$ diterima.

\section{KESIMPULAN}

Berdasarkan hasil penelitian yang telah dilaksanakan, dapat disimpulkan bahwa terdapat pengaruh dari penerapan model pembelajaran berbasis masalah terhadap aktivitas belajar siswa pada pada materi saling ketergantungan dalam ekosistem. Aktivitas belajar siswa pada kelas eksperimen yang termasuk dalam kategori sangat 
aktif persentasenya sebesar 45\%, kategori aktif $45 \%$, dan sisanya yaitu sebesar $10 \%$ termasuk ke dalam kategori cukup aktif. Pada kelas kontrol, tidak terdapat siswa yang memiliki kategori aktivitas belajar sangat aktif, tetapi hanya berkisar pada kategori aktif yaitu dengan persentase sebesar $47,61 \%$, kategori cukup aktif yaitu $42,85 \%$ dan sisanya termasuk ke dalam kategori kurang aktif yaitu dengan persentase sebesar $10 \%$. Oleh sebab itu, dapat diketahui bahwa dengan menggunakan model pembelajaran berbasis masalah tingkat aktivitas belajar siswa lebih baik pada kelas eksperimen jika dibandingkan dengan kelas kontrol yang hanya menggunakan metode diskusi informasi.

\section{UCAPAN TERIMA KASIH}

Penulis ingin mengucapkan terima kasih kepada semua pihak yang telah memberikan dukungan secara penuh atas terlaksananya penelitian ini, baik itu kepada keluarga, penguji, pembimbing, dan pihak-pihak yang terkait lainnya.

\section{DAFTAR PUSTAKA}

[1] Asiatun, A.A.I.N. 2013. Pengaruh Penerapan Model Pembelajaran Berbasis Masalah Berorientasi Biodiversitas Terhadap Aktivitas dan Prestasi Belajar IPA. Singaraja: Program Pascasarjana Universitas Pendidikan Ganesha Singaraja.

[2] Cahyo, A.N. 2013. Panduan Aplikasi Teoriteori Belajar Mengajar. Jogjakarta: DIVA Press.

[3] Dahar, R. W. 1996. Teori-teori Belajar. Jakarta: Erlangga.

[4] Djumadi, S. B. 2010. Guru dan Anak Didik. Jakarta: Rineka Cipta.

[5] Fadly, A. 2012. Peningkatan Aktivitas dan Hasil Belajar Siswa Melalui Model Pembelajaran Problem Based Learning (PBL), (Studi Pada Kelas X Bisnis dan Manajemen Mata Pelajaran Kewirausahaan di SMK Ardjuna 1 Malang). Malang: Universitas Negeri Malang.

[6] Rusman. 2014. Model-Model Pembelajaran Mengembangkan Profesionalisme Guru. Jakarta: PT. Raja Grafindo Persada.

[7] Simanjuntak. L. 2014 Metode Mengajar Matematika I. Jakarta: Rineka Cipta. 